\title{
Advancing Graduate Education and Faculty Development with Discipline Based Education Research and the SIMPLE Framework: Design Memos in Biology for Active Teaching
}

\author{
By J. Reid Schwebach ${ }^{*}$ \\ Daria Gerasimova ${ }^{\dagger}$ \\ David A. Luthert \\ Anne B. Verhoeven ${ }^{\S}$ \\ Claudette P. Davis** \\ Morgan Gostel ${ }^{\dagger \dagger}$ \\ Chelsie Romulo \\ Lisa Schreffler ${ }^{\S \S}$ \\ Padmanabhan Seshaiyer
Jill K. Nelson
}

With the increasing popularity of active teaching methods, universities have become more interested in changing instruction from direct lecture to interactive engagement. The George Mason University (Mason, Virginia, USA) Biology Department is achieving this goal through: 1) faculty participation in the SIMPLE project; 2) faculty and student involvement in Discipline-Based Education Research projects; 3) participating in the Learning Assistant program for undergraduate students as scholars; and 4) the Accelerator Program. These approaches are discussed in this paper. Also, interactive teaching strategies, which the biology faculty and graduate teaching assistants use at Mason, are documented in the form of design memos; these memos are introduced in this paper.

Keywords: active learning, biology, design memo, discipline-based education research (DBER), SIMPLE

\footnotetext{
* Coordinator, George Mason University, USA.

${ }^{\dagger}$ Graduate Student, George Mason University, USA.

\$ Term Assistant Professor, George Mason University, USA.

${ }^{\S}$ Medical Lab Science Coordinator/Term Assistant Professor, George Mason University, USA.

${ }^{* *}$ STEM Accelerator/Term-Assistant Professor, George Mason University, USA.

${ }^{\dagger}$ Graduate Student, George Mason University, USA.

*Graduate Student, George Mason University, USA.

${ }^{\S \S}$ Graduate Student, George Mason University, USA.

${ }^{* * *}$ Professor, George Mason University, USA.

${ }^{\dagger}$ Associate Professor, George Mason University, USA.
} 


\section{The Biology Department SIMPLE Group}

\section{The SIMPLE Framework}

The use of interactive teaching and active learning in STEM disciplines on a college level has been positively associated with student achievement (Freeman et al., 2014), conceptual understanding (Hake, 1998), and its retention (Gamer \& Gamer, 2001). It also increases student motivation and interest in the field (Jamieson \& Lohmann, 2009). However, despite that, it is not common for university professors to teach in this way (Fairweather, 2008). One of the obstacles, identified by research, is the lack of faculty training in teaching and pedagogy (Fiore \& Rosenquest, 2009; Hjalmarson et al., 2013). Moreover, frequently faculty do not have the skills, resources, and time necessary to implement interactive teaching (Suchman, 2014). Therefore, the need for the instructional change from traditional teacher-centered to active, student-centered is enormous (Henderson, Beach, \& Finkelstein, 2011).

The SIMPLE framework was developed to motivate and support this faculty change in teaching from lecturing to interactive engagement. According to this framework, small, discipline-driven groups of faculty have been created across and within STEM departments (Hjalmarson et al., 2014). Specifically, groups should be sustainable, focused on incremental change, include mentoring, be people-driven, emphasize interactive learning environments, and have a design focus (Hjalmarson \& Nelson, 2015). Such groups provide their participants with a friendly and supportive environment where instructors feel comfortable to discuss innovative teaching strategies suitable for their classes, talk about their experience with these strategies, share their concerns, give pieces of advice if desired, and provide additional support to each other. The research shows that the collaboration between the faculty is essential for the teaching change to occur (McKenna, Yalvac, \& Light, 2009). The faculty, participating in the project, also document the process of implementing a new interactive teaching technique in their classrooms in the form of the design memo. Such documentation is an essential component for the teaching change (Light, Calkins, Luna, \& Drane, 2009).

\section{What Design Memos Are}

For the purposes of documentation and further dissemination of the faculty experience with interactive teaching methods, design memos were developed. Each design memo is dedicated to one interactive teaching strategy the instructor practices in his/her classroom. In the design memo the instructor describes the strategy, writes about the conditions and logistics of its use, provides some examples, reflects on the advantages and challenges of its implementation as well as effects on student learning, etc. The template of the design memo can be found here: https://goo.gl/n4SyIZ.

Thus, design memos, being specific and contextual, are a useful source of information for other faculty, interested in interactive teaching. A collection of 
design memos, accessible to the teaching community, broadens the impact of the SIMPLE project by providing the instructors with an opportunity to share their own experience with interactive teaching and borrow ideas for their classrooms from others' experience. Within the SIMPLE project design memos are also used to scaffold the discussions in the groups.

\section{How the Biology Department Became Engaged in SIMPLE}

One of the primary focuses of the Biology Department at George Mason University is to enhance student learning by improving the instructors' teaching. The department aims to promote student achievement in biology courses and deepen their conceptual understanding of the subject. Participation in the SIMPLE project was viewed as one of the ways to reach this goal.

The SIMPLE group in Biology was organized by the first author. He was invited to the project as a group leader because of his previous experience with interactive teaching. During the first year of the SIMPLE project he and other group leaders prepared to lead the groups in their departments. They spent time becoming familiar with different interactive teaching strategies, looking at their research bases (e.g., student learning outcomes in the courses), while discussing these strategies with each other and planning the work of the group for the next year.

In the second year of the project the Biology group started to implement and assess engaging teaching strategies. The group consisted of the biology faculty, interested in interactive teaching, as well as select Graduate Teaching Assistants (GTAs) interested to pursue a career in academia in the future. The group members have been meeting on a regular basis during the academic year. Numerous topics were discussed at those meetings, such as the participants' experience with the implementation of the particular interactive teaching strategies, design memos, interactive teaching resources for the faculty's use, and even creation of new curriculum in the department (e.g., some of the group's participants are creating a bioinformatics curriculum). Some of the meetings were organized in the form of a journal club, where a chosenbeforehand research article about one of the interactive teaching strategies was a topic of the discussion; usually a graduate student in the group presented the article.

Overall, the instructors enjoyed their experience of participating in the group. The second year of the project showed the positive effects in the change of faculty's teaching, therefore the group will continue functioning in the following years as well, and some of the faculty and graduate students are now also participating in a form of education research termed Discipline Based Education Research (DBER) (National Research Council, 2012). 


\section{Biology Discipline-Based Education Research}

\section{Discipline-Based Education Research (DBER)}

Discipline-based education research (DBER) is a form of education research that is STEM discipline specific and inherently interdisciplinary (NRC, 2012).

The first author currently supports a Mason-wide DBER faculty group, with more than 80 faculty members interested in attending one of four DBER presentations or workshops each semester in the DBER seminar series; about 15 attend each meeting. The DBER seminars are supported by the College of Science (COS) Accelerator Program (see section 2.3). These presentations serve to engage and inform the COS and Mason faculty interested in STEM education and research to improve STEM education.

The first author's DBER work is currently supported by NSF 1240031, and a Scholarship and Development grant from Mason's Provost Office.

\section{Learning Assistants (LAs)}

The learning assistants (LAs) program is a peer-to-peer program that gives undergraduate STEM students the opportunity to facilitate in face-to-face and online collaborations between them in order to reinforce content knowledge gained in the classroom. The LAs program aims: a) to engage undergraduate students in learning in different venues, such as classrooms, labs, and help rooms with the help of LAs who already have the content knowledge of the material being taught in the particular classes and attend those classes; b) to increase the LAs' conceptual understanding of the core course material which they are assisting the course instructors to teach; and c) to introduce LAs to the nature of college teaching and student learning through engaging them in series of workshops and other activities. On a weekly basis LAs receive pedagogical training from the STEM Accelerator faculty. The purpose of the training is to familiarize them with the ways students learn best. LAs are also provided with an opportunity to present their work and experience being an LA. More information about the LAs program can be found on the university website at: http://bit.ly/1iI2XTV.

\section{The Accelerator Program at Mason}

The COS STEM Accelerator program was created in 2011 with a focus on the success of students in STEM at all levels. In particular, the program is tasked with four major goals for STEM students: increasing the number of STEM majors, improving retention rates, reducing their time to graduation, and helping them join the STEM workforce or continue their education upon completion of their Bachelor's degree. Created as an interdisciplinary unit, this division consists of faculty members from multiple departments with special 
responsibilities besides teaching, including coordinating and promoting STEM activities.

The 6 Accelerator faculty members have expertise in: math education, mathematical modeling, physics, forensic sciences, earth sciences, cell biology, and immunology. The program received as statewide recognition this year by winning the Program that Works award from the Virginia Mathematics and Science Coalition.

\section{How have Biology Learning Assistants Supported DBER?}

LAs have supported the education research efforts of a number of Accelerator faculty and COS faculty. In the Biology Department, a few faculty working with LAs have been interested to conduct research on strategies that improve education outcomes. Some of LAs intend to be K-12 teachers and are motivated to learn about education research. Since many of the LAs are returning (they had been an LA already), the Accelerator Program created a course for them.

The course is named COS 401, Discipline-Based Education Research, which is taught by the first author. In this course LAs are partnered with faculty members to conduct publication-worthy, discipline-based education research. The course was developed through a Mason Provost Grant and is designated a Research and Scholarship-Intensive course, with a special RS transcript designation. LAs in the course support the Biology Department efforts to improve curriculum, since a large number of students attending COS ( $\sim 50 \%$ of the students) and the LAs themselves are biology majors.

The course was first taught during the spring of 2015. The class was small, with only six students attending and completing research projects. Importantly, all students presented their research at a May 2015 poster colloquium and at least three are on track to submit manuscripts to peer-reviewed education journals. The other three students will continue working on their research with a faculty member and publish it too; 5 of the 6 projects are in biology (the course instructor is a Biology Department faculty member).

\section{Examples of DBER Projects}

Both graduate students and undergraduate LAs have helped with Biology DBER projects. Examples include:

- An evaluation of a Socratic notecard teaching strategy in large lecture, which helps STEM students overcome communication anxiety and engages the class (undergraduate LA project);

- An investigation of undergraduate experiences using Twitter to promote course engagement (undergraduate LA project);

- Predicting upper-class biology course performances using math placement scores (Biology SIMPLE GTA project); 
- The impact of "orals" teaching strategies on undergraduate cell biology students' grades;

- An investigation of the writing education support that GTAs need to support GTA writing instruction in STEM courses (Biology SIMPLE GTA project);

- Development of a bioinformatics curriculum at Mason (two SIMPLE GTAs are engaged).

\section{Development of a Bioinformatics Curriculum at George Mason University}

This is an emerging development for the SIMPLE group and involves the work of the Department Chair, the Biology SIMPLE group, and two new graduate students with expertise in Bioinformatics. This work is happening because the university has requested that the Biology Department create a new concentration for students, with a bioinformatics focus. With the curriculum being designed with an engaging and innovative design, the SIMPLE group is an appropriate mechanism for the faculty and graduate students to design this new biology concentration. A sub-committee of the SIMPLE group is investigating the teaching strategies of leading bioinformatics programs to determine how to go forward.

\section{Educational Research Studies in Mason's Biology Department}

Table 1 shows the research studies currently being conducted by Biology faculty, graduate students, and learning assistants. These are the projects that the SIMPLE group is participating in.

\section{Biology Design Memo Summaries}

\section{Using Notecar ds to Engage Students in a Large-Lecture Cell Biology Course}

The first author designed a Socratic teaching method that uses notecards in a large lecture cell biology learning environment. This method is an active questioning strategy, and the emerging research results (manuscript has been submitted) show the students perceive the learning to be significantly more engaging than other similar classes with direct lecture instruction. In the first class of the semester he distributes empty notecards and asks students to provide general information about themselves. Starting with the second class, he calls students' names written on notecards, poses questions to the called students, and generates whole class discussions or small group conversations. 
Table 1. Educational Research Studies in Mason's Biology Department

\begin{tabular}{|c|c|c|c|c|c|}
\hline \# & Title of the research study & Investigators & Research Question & Settings and Participants & Data Sources \\
\hline 1 & $\begin{array}{l}\text { An evaluation of a Socratic } \\
\text { notecard teaching strategy in } \\
\text { large lecture, which helps } \\
\text { STEM students overcome } \\
\text { communication anxiety and } \\
\text { engages the class. }\end{array}$ & $\begin{array}{l}\text { The first author } \\
\text { (biology faculty), and } \\
\text { learning assistants. }\end{array}$ & $\begin{array}{l}\text { How does a Socratic } \\
\text { teaching strategy help } \\
\text { students learn in large } \\
\text { lecture? }\end{array}$ & $\begin{array}{l}\text { Large lecture classroom } \\
\text { instruction. Participants: } \\
\text { undergraduate students. }\end{array}$ & $\begin{array}{l}\text { Student grades, } \\
\text { clicker reports, and } \\
\text { survey } \\
\text { information. }\end{array}$ \\
\hline 2 & $\begin{array}{l}\text { An investigation of } \\
\text { undergraduate experiences } \\
\text { using Twitter to promote course } \\
\text { engagement }\end{array}$ & $\begin{array}{l}\text { The first author } \\
\text { (biology faculty), and } \\
\text { a learning assistant } \\
\text { enrolled in COS } 401 \text {. }\end{array}$ & $\begin{array}{l}\text { How does an } \\
\text { undergraduate assistant } \\
\text { benefit learning using } \\
\text { Twitter to engage the } \\
\text { class? }\end{array}$ & $\begin{array}{l}\text { Large lecture, and out of } \\
\text { class. Participants: } \\
\text { undergraduate students. }\end{array}$ & $\begin{array}{l}\text { Student and LA } \\
\text { Twitter usage, } \\
\text { clicker reports, } \\
\text { grades, and survey } \\
\text { information. }\end{array}$ \\
\hline 3 & $\begin{array}{l}\text { Predicting upper-class biology } \\
\text { course performances using } \\
\text { math placement scores }\end{array}$ & $\begin{array}{l}\text { Graduate student, } 5^{\text {th }} \\
\text { author (biology } \\
\text { faculty), first author. }\end{array}$ & $\begin{array}{l}\text { How can math } \\
\text { placement scores be used } \\
\text { to design an intervention } \\
\text { to improve student } \\
\text { performances in biology } \\
\text { courses? }\end{array}$ & $\begin{array}{l}\text { Large lectures, lab } \\
\text { sections, analysis of } \\
\text { transcript data. } \\
\text { Participants: undergraduate } \\
\text { students. }\end{array}$ & $\begin{array}{l}\text { Student transcript } \\
\text { data, placement } \\
\text { scores, grades } \\
\text { across courses, } \\
\text { survey } \\
\text { information, } \\
\text { student interviews. }\end{array}$ \\
\hline 4 & $\begin{array}{l}\text { The impact of "orals" teaching } \\
\text { strategies on undergraduate cell } \\
\text { biology students' grades }\end{array}$ & $\begin{array}{l}\text { Learning Assistants, } \\
5^{\text {th }} \text { author (biology } \\
\text { faculty), first author, } \\
\text { Learning Assistant } \\
\text { enrolled in COS } 401 .\end{array}$ & $\begin{array}{l}\text { What small-group, } \\
\text { Learning Assistant-led } \\
\text { "orals" teaching } \\
\text { strategies improve } \\
\text { student learning? }\end{array}$ & $\begin{array}{l}\text { Large lectures, small- } \\
\text { group supplemental } \\
\text { teaching sessions. } \\
\text { Participants: Learning } \\
\text { Assistants, undergraduate } \\
\text { students. }\end{array}$ & $\begin{array}{l}\text { Student grades, } \\
\text { clicker reports, } \\
\text { survey } \\
\text { information, and } \\
\text { attendance in } \\
\text { "orals" sessions. }\end{array}$ \\
\hline 5 & $\begin{array}{l}\text { An investigation of the writing } \\
\text { education support that GTAs } \\
\text { need to support GTA writing } \\
\text { instruction in STEM courses }\end{array}$ & $\begin{array}{l}\text { Graduate student, first } \\
\text { author, } 4^{\text {th }} \text { author } \\
\text { (biology faculty). }\end{array}$ & $\begin{array}{l}\text { What preparation should } \\
\text { GTAs receive to support } \\
\text { improved undergraduate } \\
\text { writing? }\end{array}$ & $\begin{array}{l}\text { Survey of GTAs. } \\
\text { Participants: Graduate } \\
\text { students, GTAs. }\end{array}$ & $\begin{array}{l}\text { Survey } \\
\text { information, } \\
\text { workshop } \\
\text { evaluation. }\end{array}$ \\
\hline
\end{tabular}


The use of this strategy allows the instructor to: 1) make the class participation more equitable, 2) keep students on their toes and motivated to attend and participate, 3) grade and track participation, 4) diversify the ways of engaging students beyond using clickers, and 5) help students develop 21st century skills.

Going forward, the first author is investigating several strategies for questioning students in class using the cards, to better understand which strategies are most effective. He is working with undergraduate learning assistants and researchers on these investigations.

This method is described in more detail in the design memo of the first author: https://goo.gl/8CM2ZF.

\section{Evaluation of Scientific Information by Assessing Its Credibility and Validity}

The strategy, designed by the third author, aims at helping students learn how to evaluate the credibility of scientific information that they read using secondary and tertiary literature as well as popular press articles. Students start with analysis of the assigned by the instructor articles and proceed with finding their own that are of interest for them. They are expected to submit the results of their analysis to the instructor.

The use of this strategy allows the instructor to: 1) have students working in groups and learning from peers and forming social bonds while discussing biology, 2) make students seek sources of information about biology outside of their textbook, and 3) have them think critically about the information that they read.

This method is described in more detail in the design memo of the third author: https://goo.gl/GMc7kx.

\section{Means of Engaging Students with Peer Review Journal Articles in a Seminar STEM Course}

The fourth author developed a method of engaging students in senior seminar classes by using journal articles. The method includes three main parts: 1) finding a paper on a topic that describes the disease, which has no known cure, and writing a short summary prior to the class; 2 ) oral presentation of the paper in class; and 3) discussion and questions after the presentation.

Using this method, students feel connected to their unique areas of interest, take active ownership in their learning, and are more motivated to learn. Besides, the level of classroom discourse raises substantially, especially comparing to more traditional lecture classes.

This method is described in more detail in the design memo of the fourth author: https://goo.gl/AXAItE. 


\section{Mitotic and Meiotic Chromosome Movement Demonstration}

The activity was developed by the fifth author to clarify the possible misconceptions of the cell cycle and meiosis that students might have. First, students are asked to complete the worksheets, which contain a series of questions on the cell cycle and meiosis. These worksheets aim to assess students' background knowledge of these topics. As the in-class lectures continue, students have an opportunity to voluntarily participate in an activity outside of class that reinforces their understanding of mitosis and meiosis with the use of magnetic beads to depict chromosome movement. During the sessions students receive a brief review of both concepts (mitosis and meiosis). Then they are asked to demonstrate chromosome appearance at specific stages of mitosis and meiosis. At the end of the lecture series on these topics, students fill out post-assessment worksheets that contain the same questions as the first one.

The worksheets will allow the instructor to determine the level at which students actually grasp key concepts involved in the cell cycle and meiosis. Based on the scoring, the instructor can review key concepts students missed or did not understand completely, and also adapt the activity according to the revealed misconceptions.

This method is described in more detail in the design memo of the fifth author: https://goo.gl/vQQuA7.

\section{Research Immersion through "Elevator Speech" Role Play}

The "Elevator Speech" strategy was developed by the sixth author. Undergraduate students in a mid- or upper-level biology course are tasked with identifying a research laboratory in the United States that has an active, federally funded research project using the NSF Award search website. Once they identify a laboratory with a funded project, the student must conduct research to understand the proposed research well-enough to present an elevator speech as though they are an undergraduate researcher in the lab.

Variants on the "Elevator Speech" include the Three Minute Thesis (3MT), which seeks to encourage graduate and undergraduate researchers to distill their thesis or dissertation projects into an approachable, short format talk for a broad, non-scientific audience. The strategy provides another important outcome: students presenting Elevator Speeches are exposed to a number of active research laboratories that may be seeking graduate student researchers and whose research piques the interest of the student.

The use of this strategy allows the instructor to discuss active research projects with students and engage with them about challenging concepts. By researching outside of the class, students often bring questions to their instructor, which may give the instructor an important teaching opportunity. Similarly, the instructor is exposed to new, recently-funded research projects that may be of interest to their own research or provide new perspective to old approaches. 
This method is described in more detail in the design memo of the sixth author: https://goo.gl/rGmWSL.

\section{Peer Review in the Undergraduate Lab Report Assignment}

This strategy, designed by the seventh author, incorporates peer review into an undergraduate lab report assignment. The goal is to increase student understanding of the scientific method as well as the lab activity. Two weeks after completing the lab activity, students were required to bring two copies of their lab reports for in-class peer review. At the beginning of lab each student graded two other student reports using the grading rubric in the syllabus. At the end of lab each student left with two graded reports. After receiving input and grades from their peers, students had one week to incorporate revisions before turning in a draft copy for instructor review.

This strategy was selected from a series of recommendations based on a student and instructor survey completed in 2012. This survey also revealed that students did not understand the scientific method component of the lab report activity. In the past few students asked questions during lab or visited faculty office hours for help with reports. However, our course has participated in a peer mentoring program where Undergraduate Learning Assistants were available during lab time and held study sessions outside of lab. These peer-led activities had higher participation than other available study aids. This led to the development of the peer review component, implemented during the Spring of 2015.

This method is described in more detail in the design memo of the seventh author: https://goo.gl/moXNkn.

\section{Use of the "Shark Tank" Model to Solve a Current Conservation Issue}

This strategy was designed by the eighth author and aims to use the television show "Shark Tank" as a way to present a solution to a conservation issue. Fictitious entrepreneurs have three minutes to pitch an idea to fictitious millionaires who have available start-up capital. Critical thinking and creativity are emphasized. Students are required to research an issue, devise a solution, determine project costs, develop a project timeline, create a sample press kit, and present the idea to the class. Classmates vote on which project to fund.

The use of this strategy: 1) benefits the student by using critical thinking, 2) allows for current literature to be accessed and reviewed, and 3) provides the student with the freedom to be creative. The exercise also combines group work and public speaking. The three minute pitch allows students to practice communicating ideas clearly and quickly (a.k.a. the elevator speech). For the instructor, this exercise fulfils many of the course objectives (topic content, presentation skills, and critical thinking). It is also a beneficial exercise to assess understanding of an issue by not only the presenters but also by fellow classmates. 
In the future, the eighth author plans to further the exercise by attempting to add a fundraising component and possible implementation of one of the solutions. The exercise is multi-purpose, and has the ability to easily be adapted for use in other courses.

This method is described in more detail in the design memo of the eighth author: https://goo.gl/2qJk17.

\section{Conclusions and Next Steps}

One of the next steps for the group is involving more faculty and graduate teaching assistants in participating and changing their teaching from traditional, teacher-centered to active, student-centered approaches. The SIMPLE framework will also be also used in other department projects, such as trainings of graduate teaching assistants, for instance. Those trainings aim to support teaching assistants in becoming more effective and engaging instructors by participating in the SIMPLE project and collaborating with the faculty involved in it.

Besides, the SIMPLE project provides the group members with an opportunity to participate in the Teaching Inquiry group, which was designed for those faculty interested not just in implementing new interactive teaching strategies in their classrooms but also in conducting the educational research on them. This group will meet once a month during the academic year to support each other in their efforts. This process will be facilitated by a professor from the College of Education, an expert in a self-study research. Such experience will deepen the group members' understanding of their own teaching as well as provide the teaching community with a more insight on the use of the particular strategies and their research bases (Samaras, 2006).

A recent submission to the National Science Foundation from this group also exemplifies future steps. Importantly, the group plans to continue working with graduate students and involving their efforts alongside the work of the faculty. A big idea here is that key Graduate Teaching Assistants (GTAs), who have instructional roles, would have a collaborative role with the SIMPLE faculty and with other GTAs in the Department. The goal of the grant is to create Discipline-Based Education Research (DBER)-SIMPLE GTA Fellows (DS-GTA Fellows) who would work with other GTAs interested to participate in DBER and SIMPLE (these participants will be named DS-GTAs). The DSGTA Fellows would lead groups of DS-GTAs in different COS departments, and for example, in Biology the group of 5 graduate students would receive travel grants to participate, and opportunities to publish their education work. The goal is for these groups of graduate students to be better trained as future instructional faculty, and for them to create innovative instructional strategies, for example in the lab sections. The DS-GTAs would also disseminate their innovations as design memos to the other graduate students and faculty. At the end of the fellowship year (the start of the next school-year, in August), the Fellows would have a leading role in the COS training of new GTAs. 


\section{References}

Fairweather, J. (2008). Linking evidence and promising practices in science, technology, engineering, and mathematics (STEM) undergraduate education. Board of Science Education, National Research Council, The National Academies, Washington, DC.

Fiore, L., \& Rosenquest, B. (2009). Shifting the culture of higher education: Influences on students, teachers, and pedagogy. Theory Into Practice, 49(1), 14 20. http://doi.org/10.1080/00405840903435535.

Freeman, S., Eddy, S. L., McDonough, M., Smith, M. K., Okoroafor, N., Jordt, H., \& Wenderoth, M. P. (2014). Active learning increases student performance in science, engineering, and mathematics. PNAS Early Edition. http://doi.org/ 10.1073/pnas.1319030111.

Gamer, B. E., \& Gamer, L. E. (2001). Retention of concepts and skills in traditional and reformed applied calculus. Mathematics Education Research Journal, 13(3), 165-184. http://doi.org/10.1007/BF03217107.

Hake, R. R. (1998). Interactive-engagement versus traditional methods: A sixthousand-student survey of mechanics test data for introductory physics courses. American Journal of Physics, 66(1), 64-74. http://doi.org/10.1119/1.18809.

Henderson, C., Beach, A., \& Finkelstein, N. (2011). Facilitating change in undergraduate STEM instructional practices: An analytic review of the literature. Journal of Research in Science Teaching, 48(8), 952-984. http://doi.org/10.1002/ tea.20439.

Hjalmarson, M., Nelson, J. K., Huettel, L. G., Padgett, W. T., Wage, K. E., \& Buck, J. R. (2013). Developing interactive teaching strategies for electrical engineering faculty. Presented at the ASEE Annual Conference and Exposition, Atlanta, GA.

Hjalmarson, M., Nelson, J. K., Huettel, L. G., Padgett, W. T., Wage, K. E., \& Buck, J. R. (2014). Creating small interactive teaching development groups. Presented at the ASEE Annual Conference and Exposition, Indianapolis, IN.

Hjalmarson, M., \& Nelson, J. (2015). The Five "S" Model for Implementing Interactive Teaching Design Groups: A Design Research Process. Unpublished manuscript.

Jamieson, L., \& Lohmann, J. (2009). Creating a culture for scholarly and systematic innovation in engineering education: Ensuring U.S. engineering has the right people with the right talent for a global society (No. 0743223). Washington, DC: American Society for Engineering Education. Retrieved from http://bit.ly/1FoYhMn.

Light, G., Calkins, S., Luna, M., \& Drane, D. (2009). Assessing the impact of a yearlong faculty development program on faculty approaches to teaching. International Journal of Teaching and Learning in Higher Education, 20(2), $168-181$.

McKenna, A. F., Yalvac, B., \& Light, G. J. (2009). The role of collaborative reflection on shaping engineering faculty teaching approaches. Journal of Engineering Education, 98(1), 17-26. http://doi.org/10.1002/j.2168-9830.2009.tb01002.x.

National Research Council (2012). Discipline-based education research: Understanding and improving learning in undergraduate science and engineering. (S. R. Singer, N. R. Nielsen, \& H. A. Schweingruber, Eds.). Washington D.C.: The National Academies Press.

Samaras, A. P., \& Freese, A. R. (2006). Self-study of teaching practices. New York, NY: Peter Lang Publishing, Inc. 
Suchman, E. L. (2014). Changing academic culture to improve undergraduate STEM education. Trends in Microbiology, 22(12), 657-659. http://doi.org/ 10.1016/ j.tim.2014.09.006. 
